EWA WOLNICZ-PAWLOWSKA

Uniwersytet Warszawski

ewolnicz@uw.edu.pl
DOI: http://x.doi.org/10.17651/ONOMAST.61.2.11

Onomastica LXI/2, 2017 PL ISSN 0078-4648

\title{
SŁOWA TEMATYCZNE W .ONOMASTIKACH” (ZAKRES, TREŚĆ, FORMA)
}

S lowa tematyczne: słowo tematyczne, wyraz kluczowy, „Onomastica”

Ujednolicanie ludzkiej działalności w sferze publicznej, polegające na wyznaczeniu parametrów umożliwiających formalne porównywanie, znalazło wyraz także w publikacjach naukowych. Po 1989 r. w Polsce przemodelowano wymagania stawiane autorom artykułów w periodykach naukowych, wprowadzono na wzór amerykański obowiązek podawania streszczeń i słów kluczowych w języku „kongresowym" (w praktyce szybko ograniczono to do języka angielskiego). Umożliwilo to m.in. porównanie tzw. punktacji czasopism krajowych i zagranicznych, a dalej - określanie poziomu dofinansowania.

W „Onomastikach” wymóg podawania słów tematycznych pojawia się dopiero w roczniku za 2002 r. ${ }^{1}$; w tymże numerze słowa tematyczne już zastosowano. W numerze z 2003 r. jeszcze nie wszystkie artykuly zaopatrzono w polskie słowa tematyczne, przy niektórych tekstach podawano na przykład tylko angielskie ${ }^{2}$. W późniejszych numerach przestrzegano zasady zamieszczania słów tematycznych, choć nie wypracowano początkowo formuly, czy mają to być słowa w języku polskim, czy obcym (lub w obu naraz) i jaka jest ich zależność od języka tekstu glównego. W ciągu 15 lat autorzy publikujący w „Onomastikach" zaproponowali przeszło tysiąc "słów tematycznych". W swoich badaniach uwzględniłam jednostki wydzielone w tym czasopiśmie jako „słowa tematyczne” na początku lub końcu artykulu, przy czym zebralam tylko wyrazy polskie (zamieszczane zarówno przy artykułach pisanych po polsku, jak i w innych językach), pominęlam natomiast formy obcojęzyczne (angielskie, czeskie, rosyjskie, bulgarskie itp.).

1 „Do rozpraw i artykułów winno być dolączone kilkuzdaniowe streszczenie w języku polskim oraz słowa tematyczne; dotyczy to także tekstów obcojęzycznych" (Instrukcja dla autorów, Onomastica, XLVIII, 2002, trzecia strona okładki).

2 Tak jest w artykule E. Pieciul „Nazwiska żydowskie w powieściach Tomasza Manna i ich przekładach na polski, na przykładzie powieści «Buddenbrookowie» i «Czarodziejska Góra»”. 
W językoznawstwie o „slowach kluczowych” (inaczej: „wyrazach kluczowych”, ,slowach kluczach”, ,wyrazach kluczach”) mówi się od czasów Pierre’a Guirauda (1954) i jego koncepcji badań stylistycznych metodami statystycznymi. Na gruncie polskim metody te rozpowszechnily się (nie tylko w stylistyce) w dużej mierze za sprawą Jadwigi Sambor, która w swojej monografii o slownictwie „Pana Tadeusza” (Sambor, 1969) ustawila bardzo wysoko poprzeczkę dla prac językoznawczych wykorzystujących w metodologii statystykę. W wielu swoich opracowaniach wskazywala ona na rozróżnienie pojęciowe (i terminologiczne) „slów kluczowych" i „slów tematycznych".

Slowa kluczowe to wyrazy charakterystyczne dla danego tekstu (także autora, stylu, gatunku itp.), przy czym „charakterystyczność” rozumie się jako zwiększoną frekwencję tych wyrazów w stosunku do ogólnych list frekwencyjnych w danym języku. Jest to więc, jak podkreślala J. Sambor, pojęcie relacyjne: aby uznać jakieś wyrazy za „kluczowe” dla naszego tekstu, musimy porównać slownictwo tego tekstu ,ze slownictwem przeciętnym, uznanym za normę, podaną w ogólnym slowniku frekwencyjnym" (Sambor, 2001, s. 519). Pokrewnym pojęciem są slowa tematyczne. W przeciwieństwie do słów kluczowych nie jest to pojęcie relacyjne, ponieważ odnosi się do najwyższej frekwencji wyrazów niegramatycznych w obrębie danego tekstu (tekstów danego autora, danego stylu itp.). Wedlug J. Sambor, ,pojęcia te pozostają w relacji inkluzji, tzn. wszystkie wyrazy klucze są równocześnie tematyczne, ale nie odwrotnie" (tamże).

Większość terminów w tekstach onomastycznych mieści się w kategorii slów kluczowych. Dla każdego tekstu naukowego istotne są słowa tematyczne (pojęcie szersze), które wskazują na przedmiot badań i ich zakres. Z terminologicznego punktu widzenia w „Onomastikach" jak najbardziej slusznie wymaga się „stów tematycznych". W praktyce polskiej jednak pod wplywem ang. key words bardziej rozpowszechnionym terminem jest wyraz kluczowy (słowo kluczowe), stosowany w informacji bibliotecznej i językoznawstwie komputerowym ${ }^{3}$.

Starsze pokolenia autorów przyjęly wymóg podania słów tematycznych ze zrozumieniem, ale i bez specjalnego zaangażowania. Taka konwencja wydawnicza w czasopismach i tomach zbiorowych byla już znana z publikacji zachodnioeuropejskich i amerykańskich, podobnie jak obowiązek dołączania streszczeń i abstraktów w językach światowych ${ }^{4}$. Mlodsze pokolenia zetknęly się z pojęcia-

${ }^{3}$ Zauważmy, że w polskich artykułach (lub polskich streszczeniach) w "Onomastikach" podawane są slowa tematyczne, ale tamże, w artykułach i streszczeniach pisanych po angielsku, key words. Z tego względu w dalszej części artykułu stosuję oba terminy: slowo tematyczne i wyraz kluczowy wymiennie.

${ }^{4}$ Co do rozróżnienia abstraktów i streszczen̉ w polskiej praktyce wydawniczej, uważam to za problem wart przestudiowania, tutaj jednak tylko go sygnalizuję bez dalszych analiz. 
mi słów kluczowych i streszczeń podczas przygotowywania prac dyplomowych: licencjackich i magisterskich, takie są bowiem wymogi zapisane w instrukcji dla dyplomantów (cytuję za „Instrukcją dla pracy magisterskiej” na Uniwersytecie Warszawskim):

Słowa kluczowe (maksymalnie 10), tworzone przede wszystkim na podstawie tytułu i streszczenia, powinny być formułowane w mianowniku liczby pojedynczej. Należy je zapisać w wierszu, oddzielone przecinkami.

Streszczen i e nie powinno zawierać więcej niż 800 znaków (około 16 wierszy).

Siłą rzeczy, słowa kluczowe (a także streszczenie i abstrakt) są pojęciami i terminami, z którymi ma do czynienia każdy dydaktyk-opiekun prac dyplomowych. Zauważmy, że choć nie jest to zapisane we wspomnianej instrukcji, to konieczność stosowania „mianownika liczby pojedynczej” sugeruje użycie przede wszystkim rzeczowników.

Obowiązek podania slów tematycznych dyscyplinuje w pewien sposób autora, każe mu przeanalizować wlasny tekst, jego strukturę i stosowaną terminologię. Streszczenia, abstrakty i slowa kluczowe (a także — dodajmy — tytuly) to teksty wtórne, przetworzone w stosunku do tekstu artykułu. W przypadku slów kluczowych wymagane jest podanie dominant pojęciowych, wokól których autor organizuje swoją wypowiedź. To według nich czytelnik najszybciej zorientuje się, czy dany tekst będzie mu przydatny, czy nie (tak też dzialają wyszukiwarki).

Jedno z pytań badawczych, jakie sobie postawiłam, brzmi: czy z czasem zmieniała się jakość slów tematycznych i ich forma? Czy mlodsi autorzy publikujący w „Onomastikach" wykorzystują swoją wiedzę i przyzwyczajenia pokolenia internetu do budowy modelowych tekstów, zamieszczanych w artykułach jako slowa tematyczne ${ }^{5}$. Szczególowa analiza obejmowała przebadanie ogólnej liczby tych jednostek w badanym zbiorze ${ }^{6}$, liczby jednostek powtarzających się co najmniej dwa razy, przeciętnej liczby stów tematycznych w jednym artykule, największej i najmniejszej ich liczby w jednym artykule, liczby elementów w odrębnej jednostce „słowo tematyczne”, zasad porządkowania w obrębie jednego artykułu. Ogólne dane dotyczące wykorzystanego zbioru pokazuje tabela 1 .

\footnotetext{
${ }^{5}$ Nie ulega wątpliwości, że autorzy traktują swoje zbiory slỏw tematycznych jako tekst spójny; świadczy o tym np. użycie pojęć uzupełniających się lub przeciwstawnych, spójnikỏw i innych wykladników koherencji i kohezji. Temat ten przedstawię w odrębnym artykule.

${ }^{6}$ Zasadniczo za jednostkę (słowo tematyczne) przyjęłam wyrażenia oddzielone przecinkami. W nielicznych zapisach można mieć wątpliwości, czy chodzi o część składową, czy o odrębne slowo, por. niżej przykłady.
} 
Tabela 1. Slowa tematyczne w czasopiśmie „Onomastica” w latach 2002-2016

\begin{tabular}{|l|c|}
\hline Liczba wykorzystanych artykułów & 211 \\
\hline Ogólna liczba „słów tematycznych” & 979 \\
\hline Liczba odrębnych jednostek („stów”) & 681 \\
\hline W tym: & 117 (ok. 17\%) \\
\hline Powtarzające się co najmniej 2 razy & 564 \\
\hline Niepowtarzające się & $4-5$ \\
\hline Przeciętna liczba słów tematycznych w jednym artykule & $2-11$ \\
\hline Najmniejsza i największa liczba „słów” w jednym artykule & $1-10$ \\
\hline Liczba elementów w jednostce ,słowo tematyczne” & \\
\hline
\end{tabular}

W badanym zbiorze zdecydowanie przeważaly rzeczowniki i wyrażenia imienne $\mathrm{z}$ rzeczownikiem jako ośrodkiem syntaktycznym. Wyjątkowo pojawily się przymiotniki jako odrębne:jednostki i to tylko przy jednym artykule z $2006 \mathrm{r}$.: chrześcijański, muzulmański, słowiański, żydowski.

W slowach tematycznych widać znaczny stopień indywidualizacji: ponad $80 \%$ jednostek pojawia się tylko raz. W dodatku niektóre powtarzające się wystapily w artykulach tego samego autora, podzielonych np. ze względu na objętość na dwie czy trzy części. Wskażę kilka przyczyn tak wysokiego odsetka słów, które się nie powtarzają. Jedną z nich jest wariantywność terminologiczna, do której wrócę w dalszej cześci artykułu. Inną - dodawanie elementów dyferencyjnych (często przymiotników, choć nie tylko), które z szerszego zbioru wyodrębniają podrzędny, np. adaptacje nazw niemieckich, dwuelementowe nazwisko malżonki, nazwisko odajcowskie (panieńskie), nazwy przedsiębiorstw budowlanych, polska i stowiańska terminologia onomastyczna, zoonimia regionalna, toponimy rodzaju męskiego, urbonimy z imionami władców, historia języka polskiego w'XX wieku. Wydaje się, że uwaga większości autorów skupia się przede wszystkim na tym, co ich badania wyróżnia od innych, mniej natomiast troski poświęcają umiejscowieniu swoich osiagnięć w szerszej siatce pojęciowej. Charakterystyczne, że nawet słowa o największej frekwencji powtarzają się w zbiorze zaledwie po dwadzieścia kilka, kilkanaście razy (zob. tabelę 2) na 681 odrębnych jednostek. Są to: antroponimia, onomastyka, etymologia, imiona. Najwięcej, bo aż 66 przykladów, to slowa tematyczne pojawiające się tylko w dwóch artykulach. 
Tabela 2. Słowa tematyczne powtarzające się w zbiorze

\begin{tabular}{|c|c|c|l|}
\hline Lp. & $\begin{array}{c}\text { Liczba } \\
\text { wystąpién }\end{array}$ & $\begin{array}{c}\text { Liczba } \\
\text { przykladów }\end{array}$ & \multicolumn{1}{|l|}{ Przykład } \\
\hline 1. & 23 & 1 & antroponimia \\
\hline 2. & 18 & 1 & onomastyka \\
\hline 3. & 14 & 1 & etymologia \\
\hline 4. & 12 & 1 & imiona \\
\hline 5. & 8 & 3 & motywacja, slowotwórstwo, toponimia \\
\hline 6. & 7 & 6 & nazwisko, onimizacja, toponimy \\
\hline 7. & 6 & 3 & nazwiska, nazwy wlasne, onomastyka literacka \\
\hline 8. & 5 & 7 & frekwencja, przezwiska, semantyka \\
\hline 9. & 4 & 8 & antroponim, chrematonimia, jezykowy obraz świata \\
\hline 10. & 3 & 20 & apelatywizacja, imię, metafora \\
\hline 11. & 2 & 66 & adaptacja, etnonim, gwara \\
\hline
\end{tabular}

Na wysoki stopień indywidualizacji słów tematycznych wplywa także użycie nazw własnych, z natury swojej jednostkowych. W badanym zbiorze stanowią one sporą grupę (zob. tabelę 3 ).

Tabela 3. Nazwy wlasne jako słowa tematyczne

\begin{tabular}{|l|l|}
\hline Odrębne słowa tematyczne & 48 \\
\hline Składowe słowa tematycznego & 32 \\
\hline
\end{tabular}

Pojawiają się bądź jako odrębne „slowa tematyczne”, np.: Alaska, Butgaria, Warmia, Bieszczady Zachodnie, Hieronim Morsztyn, bądź jako ich części, np.: arcybiskup Leszek Sławoj Głódź, dorzecze Wieprzówki, imię Maria. Łacznie wynotowalam 75 nazw własnych, użytych 80 razy (niektóre się powtarzały, np.: Warmia, Karpaty, Pomorze Zachodnie; zob. Aneksy).

Przeciętnie w jednym artykule podawano 4-5, słów tematycznych", chociaż kilkakrotnic autorzy ograniczyli się tylko do dwóch jednostek, np.: Mlawa,przedstowianska hydronimia w Polsce; antroponimia pogranicza, nazwiska szlacheckie; hodonimy polskie i francuskie, techniki przekladu; imiona chrześcijańskie, imiona pochodzace od nazw świat i atrybutów Matki Bozej uzywane i nieuzywane $w$ Polsce. Na drugim krańcu znalazly się artykuly, w których wymieniano 10-11 słów, np. termin topograficzny, toponim, antroponim, hydronim, ojkonim, oronim, nazwa terenowa, semantyka, etymologia, motywacja, metodologia.

Liczbę elementów składowych w obrębic słowa tematycznego pokazuje tabela 4. Zgodnic z definicją słów tematycznych liczyłam tylko wyrazy niegrama- 
tyczne. Słowa tematyczne składające się z niewielu elementów (1-4) stanowily $97 \%$ ogólu materiału, slowa wieloelementowe (5-10) to zaledwie 3\%. Można zauważyć pewną zależność: wieloelementowych słów tematycznych w jednym artykule jest niewiele, tam zaś, gdzie autorzy podali ich dużą liczbę, byly one zazwyczaj krótkie. Widać to choćby w podanych wyżej przykladach.

W wielu slowach tematycznych autorzy lączyli dwa zagadnienia, dwa terminy (za pomocą spójnika lub przecinka), zapewne w celu uzyskania zwięzlości wypowiedzi, np. imiona rodzime (tradycyjne) $i$ imiona obce; adaptacja fonetyczna i morfologiczna; imiona slowiańskie, chrześcijańskie; cechy i typy gier onimicznych; charakterystyka formalna i znaczenie toponimów; język chiński, japoński. Nie jest to fortunne rozwiązanie, ponieważ takie ,slowa tematyczne” mogą budzić wątpliwości odbiorcy: czy chodzi o imiona słowiańskie skontrastowane z chrześcijańskimi, czy o imiona slowiańskie, które staly się chrześcijańskimi; czy chodzi o adaptację fonetyczną $i$ adaptację morfologiczną (osobno omówione), czy o adaptację mieszaną, lączącą fonetykę z morfologią. Zapis z przecinkiem w obrębie danej jednostki stoi poza tym w sprzeczności z zasadą, że w polu ,słowa tematyczne" przecinkami oddzielone są od siebie osobne jednostki. Również stosowanie myślników może prowadzić do nieporozumień, nie wiadomo, gdzie kończy się jeden wyraz kluczowy, a zaczyna drugi, por. ciąg w jednym z artykulów: onomastykapolska, onomastyka stowiańska, podziat wewnętrzny duscypliny - kryterium przedmiotowe, kryterium metodologiczne, dorobek naukowo-badawczy, kierunki badawcze, tendencje rozwojowe wyznaczniki, zadania badawcze.

Tabela 4. Liczba elementów składowych w jednostce "słowo tematyczne"

\begin{tabular}{|c|c|r|l|}
\hline $\begin{array}{c}\text { Liczba } \\
\text { elementów }\end{array}$ & $\begin{array}{c}\text { Liczba } \\
\text { przykładów }\end{array}$ & {$[\%]$} & \multicolumn{1}{|c|}{ Przykład } \\
\hline 1 & 232 & 34 & chrematonimia \\
\hline 2 & 300 & 44 & antroponimia historyczna \\
\hline 3 & 96 & 14 & analiza materialu antroponimicznego \\
\hline 4 & 34 & 5 & etymologie różnych typów nazwisk \\
\hline & 9 & 97 & \\
\hline 5 & 4 & & formy gwarowe nazw toni rybackich \\
\hline 6 & 3 & & $\begin{array}{l}\text { komponenty kategorialne (toponimia, antroponimia, } \\
\text { zoonimia, kosmonimia, chrematonimia) }\end{array}$ \\
\hline 7 & 1 & & $\begin{array}{l}\text { funkcje: identyfikacja, fikcjonalizacjaliluzjonizacja, } \\
\text { charakteryzacja, mitologizacja, akcentuacjal anonimizacja }\end{array}$ \\
\hline 8 & 2 & & $\begin{array}{l}\text { imiona pochodzace odnazw świat i atrybutów Matki } \\
\text { Bożej uzywane i nieuzywane w Polsce }\end{array}$ \\
\hline 10 & & 3 & \\
\hline & &
\end{tabular}


Od strony praktycznej istnieje także problem, jak w wykazie rzeczowym dotrzeć do treści tych elementów slowa, które występują na drugiej pozycji, np.: typy gier onimicznych (w jednostce: cechy i typy gier onimicznych), znaczenie toponimów (w jednostce: charakterystyka formalna i znaczenie toponimów), język japoński (w jednostce: język chiński, japoński). Podobny problem pojawia się przy wyrazach kluczowych zawierajacych nawias z doprecyzowującym wyrażeniem, np. antroponimy przezwiskowe (przezwiska), derywacja semantyczna (nazwy metaforyczne), komponenty kategorialne (toponimia, antroponimia, zoonimia, kosmonimia, chrematonimia), kultura duchowa (symboliczna).

$\mathrm{Na}$ krytyczną ocenę zaslugują również slowa tematyczne zbyt ogólne, slabo charakteryzujące tekst przez wieloznaczność lub szeroki zakres znaczeniowy, jak np.: gra, kultura, podzial, przejrzystość. Domyślić się treści takich wyrazów można $\mathrm{w}$ połączeniu z pozostalymi wyrazami w ciagu, ale nie zawsze ${ }^{7}$. Funkcjonalne nie są również sformulowania wieloelementowe, np.: nazwy miejscowe, Przylubie, Przylubsko, Przylubia, etymologiapodstawy; nazwy osobowe od apelatywów określajacych powinności; toponimy typu Łaz, Łazy oraz pochodne od określeń należacych do pola semantycznego OGIEŃ. Tego typu zapisy dublują w gruncie rzeczy tytul artykulu.

Trzy pierwsze pozycje w tabeli 4: jednostki jedno-, dwu- i trzyelementowe stanowią lącznie 92\% wszystkich slów tematycznych. Taka struktura zbioru jest zbliżona do struktury wielu zbiorów terminologicznych. O podobieństwie świadczy również szyk w jednostkach dwuelementowych o budowie: rzeczownik + przymiotnik (np. imię rodzime). Pozycja przymiotnika na drugim miejscu jest typowa dla terminologii, w przeciwieństwie do szyku w swobodnej wypowiedzi z przymiotnikiem na pierwszym miejscu (*rodzime imię).

Wedlug S. Gajdy (1990) teksty naukowe charakteryzują się slownictwem abstrakcyjnym i wyrazami tematycznymi związanymi z daną dyscypliną. Jest oczywiste, że w zbiorze wyrazów tematycznych nasycenie terminami jest bardzo duże, chociaż, jak wynika $\mathrm{z}$ dotychczasowych rozważan, nie wszystkie słowa tematyczne są zarazem terminami. W badanym zbiorze wystąpily terminy o nom ast y c zne (np.: antroponimia, choronim, hydronimy, nazwisko, patronimicum, toponim), terminy ogólnojęzykoznawcze (np.: derywacja, dialekt, etymologia, język, rzeczownik, stownik, slowotwórstwo) i terminy o gólno na ukowe (np.: adaptacja, funkcja, klasyfikacja, motywacja, teoria, typ). W każdej z tych grup wystąpiła relacja nadrzędności-podrzędności ze względu na zakres znaczeniowy, np.:

${ }^{7}$ Por. uwagi w przypisie 5. 


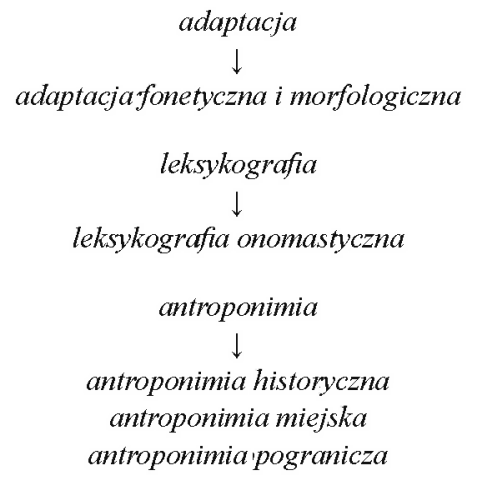

Terminy komplementarne wobec siebie, np.: imiona męskie, imiona żeńskie; imiona rodzime (tradycyjne) i imiona obce; przejrzystosśc, nieprzejrzystość, to cecha nie calego badanego zbioru, ale wyrazów kluczowych w danym artykule.

W grupie terminów występujących w badanym zbiorze można zaobserwować zjawiska typowe dla polskiej terminologii onomastycznej ${ }^{8}$. Zdaniem jej badaczy (np. E. Rzetelska-Feleszko, R. Mrózek, A. Cieślikowa, Z. Abramowicz, L. Dacewicz) synonimia stanowi trwałą cechẹ polskiej terminologii językoznawczej w ogóle. Przejawia się we współwystępowaniu terminów wywodzących się głównie z greki (adaptowanych fonetycznie i morfologicznie) i rodzimych, np.: onimy - nazwy wlasne, antroponim - nazwa osobowa. Synonimia terminologiczna przybiera niekiedy postać ciągów (np. łac. patronymicum - formy adaptowane i zmienione: patronimicum, patronimikum, pol. nazwa odojcowska itp.). Przyczyną dubletów polskich jest brak stabilnego wzorca, standardu terminologicznego, stąd np.: imiona chrześcijańskie i imiona osobowe pochodzenia chrześcijanskiego; motywacje imiennicze i motywacje wyboru imienia. Dotyczy to również liczby gramatycznej. W przywołanej na początku artykułu „Instrukcji dla pracy magisterskiej” zalecano stosowanie liczby pojedynczej. W pracach językoznawczych niekiedy liczba pojedyncza nie może zastąpić liczby mnogiej, por. np. języki ugrofinskie. W wielu innych przykladach ujednolicenie formuly liczby gramatycznej w slowach tematycznych byloby jednak wskazane, $\mathrm{np}$ :

- sg. adaptacja; adaptacjafonetyczna i morfologiczna, pl. adaptacje; adaptacje nazw niemieckich;

- sg. antroponim, pl. antroponimy; antroponimy w kulturze Gluchych; antroponimy przezwiskowe (przezwiska);

- sg. choronim, pl. choronimy;

${ }^{8}$ Por. ostatnio na ten temat: E. Wolnicz-Pawłowska (2016). Terminologia onomastyczna w tradycji badawczej i praktyce normalizacyjnej. Onomastica, LX, s. 37-46. 
- sg. chrematonim, pl. chrematonimy;

- sg. nazwa miejscowa, pl. nazwy miejscowe itp.

Lącznie tego typu dublety z liczbą gramatyczną wystapily 35 razy.

W grupie terminów warto zwrócić uwagę na określenia nowe, czasem tworzone przez autorów opracowań, np.: ampelonim, aptonimy, autografonim, demononimia, enonim, enoturystyka itp. Najczęściej jednak nowy termin stanowi uszczególowienie dotychczasowego, np.: ergonimia komercyjna, kosmonimia globalna, ojkoleksem, ojkosufiks. Takie słowa tematyczne (wyrazy kluczowe) mogą przyczynić się do uzupelnienia onomastycznego leksykonu terminologicznego i wspomóc przyszly słownik terminologii onomastycznej.

Co do zasad porządkowania slów tematycznych, to wspólwystępują dwie: wedlug kolejności pojawiania się w tekście glównym oraz (rzadziej) wedlug stopnia ogólności (np.: internet, anonse towarzysko-matrymonialne, antroponi$m y$ ). W.jednym artykule zastosowano układ alfabetyczny.

Postawilam na wstępie pytanie: czy z biegiem czasu widać sprawniejsze formulowanie słów tematycznych? Wydaje się, że istotnie, praktyka ma wpływ na ich lepszą funkcjonalność. Porównalam pięć pierwszych badanych roczników (lata 2002-2006) oraz pięć ostatnich (lata 2012-2016), licząc występowanie slów wieloelementowych (5-10) oraz takich wyrazów kluczowych, które zawieraly przecinki, spójniki, myślniki, nawiasy itp. Takich jednostek bylo w latach 2002-2006 34, w latach 2012-2016 zaś 22. Wydaje się więc, że autorzy lepiej sobie radzą z formulowaniem słów kluczowych.

Ogląd zebranego materiału, a także obserwacje wlasne i kolegów prowadzących bibliografię językoznawstwa slawistycznego w programie iSybislaw, pokazują, że slowa tematyczne, wyrazy kluczowe są niedocenianym narzędziem metodologicznym. Slowa te są potrzebne odbiorcy, bo stosunkowo latwo pozwalają ocenić, czy tekst zawiera interesujące czytelnika treści (po tytule nie zawsze można się zorientować), pozwalają również szybko znaleźć konkretny artykuł np. w wyszukiwarkach internetowych czy indeksach rzeczowych. Ale słowa te są także potrzebne autorowi do poglębionej konceptualizacji swojego tekstu, poddania go rygorom jasności, prostoty, zwięzłości i precyzji stylu, tak pożądanym w literaturze naukowej.

\section{LITERATURA'}

Gaj d a, S. (1990). Współczesna polszczyzna naukowa. Język czy żargon? Opole: Wyd. Instytutu Sląskiego.

Guira ud, P. (1954). Les caracteres statistiques du vocabulaire: Essai de methodologie. Paris: Presses Universitaires de France. 
S a mbor, J. (1969). Badania statystyczne nad słownictwem (na materiale „Pana Tadeusza”). Wroclaw [itd.]: Ossolineum.

S a m b o r, J. (2001). Język polski w świetle statystyki. W: J. Bartmiński (red.), Wspólczesny język polski. Lublin: Wyd. UMCS, s. 503-526.

Woln icz-Pawłowska, E. (2016). Terminologia onomastyczna w tradycji badawczej i praktyce normalizacyjnej. Onomastica, LX, s. 37-46.

\section{SUMMARY}

KEY WORDS IN "ONOMASTICA" (QUANTITY, CONTENT, FORM)

Key words are in Poland an unappreciated methodological tool. Polish editors have required key words to be given in scientific papers since the end of the $20^{\text {th }}$ century. Key words have been used by the journal "Onomastica" since 2002 (vol. XLVIII). The present paper discusses preliminary research that aims at describing the quantity, content, and structure of key words given in the papers published in "Onomastica" issues from the years 2002-2016. The author analysed 211 papers containing 979 key words in Polish. 681 key words are formally unique units. Most of the 681 key words are individual terms (coined by the authors of the papers) or proper names. Only 17 percent of keywords occurred in more than one article. The analysed set of key words contains many general scientific terms as well as many linguistic and onomastic terms. Among the latter, a low presence of fixed terminology is to be noticed. This paper points out formal and functional inadequacies of key words present in the analysed set, though an improvement is to be seen in the recent years.

Key words: thematic word, key word, "Onomastica" 


\author{
ANEKSY \\ Słowa tematyczne występujące co najmniej dwukrotnie \\ (do tabeli 2)
}

antroponimia (23); onomastyka (18); etymologia (14); imiona (12); motywacja, slowotwórstwo, toponimia (8); nazwa miejscowa, nazwa wodna, nazwisko, onimizacja, onomastyka kulturowa, toponimy (7); nazwiska, nazwy wlasne, onomastyka literacka (6); frekwencja, klasyfikacja, nazwa wlasna, nazwy geograficzne, przezwiska, semantyka, struktura (5); antroponim, chrematonimia, językowy obraz świata, nazwa osobowa, nazwy terenowe, staroruskie imiennictwo osobowe, Warmia, znaczenie nazw (4); apelatywizacja, geografia nazewnicza, hipokorystyka, hydronimy, imię, język starorosyjski, konotacja, metafora, metodologia, nazwy osobowe, odapelatywne nazwy osobowe, onomastyka polska i slowiańska, oronimy, postmodernizm, struktura nazw, tekst, toponim, transonimizacja, urbanonimia, wartościowanie (3); adaptacja, chrematonimy, deonimizacja, derywacja, diachronia, dialekt kreteński, dialektologia, dyskurs naukowy, ergonimy, etnolingwistyka, etnonim, etymologia ludowa, fleksja toponimów, fonetyka, geografia, globalizacja, gra językowa, gwara, hydronimia, hydronimia polska, imiona dwuczłonowe, imiona męskie, imiona żeńskie, Internet (także w zapisie: internet), język niemiecki, język nowogrecki, język polski, język religijny, język rosyjski, Karpaty, kategoryzacja, kierunki badawcze, konotacje, Kraków, kultura, metonimia, mikrotoponimia, mikrotoponimy, mitologia stowiańska, moda imiennicza, Moldawia (Bielce, Styrcza), nazwotwórstwo, nazwy firm, nazwy marketingowe, nazwy obce, nazwy pamiątkowe, ojkonim, ojkonimy, Onomastica (także w zapisie: „Onomastica”), plurale tantum, polska etymologia toponimiczna, Pomorze Zachodnie, pragmatyka nazewnicza, przekład, reklama, semiotyka, singularia tantum, statystyka, struktura proprialna, teonimia, toponomastyka, typologia slowiańskich nazw miejscowych, wieloimienność, współczesna hydronimia grecka, zmiany fonetyczne, zoonimy (2).

$$
\text { Nazwy wlasne w słowach tematycznych }
$$

$$
\text { (do tabeli 3) }
$$

Alaska, Barok, Biblia, Biblia gdańska, Bielce, Bieszczady Zachodnie, Biskupizna, Bułgaria, Bydlin, Clematis, Daleki Wschód, Episkopat Polski, F-16 Jastrząb, Glusi, Gorce, Hieronim Morsztyn, Hydronymia Europaea, Jaćwięgowie, Jezioro Szczutowskie, Jezioro Urszulewskie, Jurij Lisianski, Karpaty, Kazimierz, Kielce, Kościól, Kościoly, Kotorydz, Kraków, Kresy Wschodnie, Królestwo Polskie, Kseksoły, Litwa, Laz, Lazy, Lódź, Maria, Matka Boża, Mazowsze, Mazury, Mlawa, Moldawia, Naruszewo, Onomastica, Pasmo Brzanki, Plyćwia, Płytwica, Pogórze Ciężkowickie, Polacy, Polonia, Polska, Pomorze Zachodnie, Przedświt, „Przeds̉wit”, Przyłubie, Przyłubien̉, Przyłubsko, Reszel, Rosja, Sławoj Leszek Glódź, Słowacki, Styrcza, Suwalszczyzna, Szczutowo, Urszulewo, Warmia, Wągra Potok, Węgierka, Węgra, Węgrów, Wielkopolska, Wieprzówka, Witkacy, Wrocław, Wujek, Zagłębie Ruhry 